\title{
Learner Autonomy in EFL: Senior High School Teachers' Perception and Practices
}

\author{
Sudarsono $^{1)}$ Prof. Dr. Lies Amien Lestari, MA, M.Pd ${ }^{2)}$ Slamet Setyawan, PhD $^{3)}$ \\ ${ }^{1,2,3)}$ State University of Surabaya, Indonesia
}

\begin{abstract}
Topic about Learner autonomy (LA) is still interesting and trending for English Language teachers or researchers. This research aims to findhow senior high school teachers percieve the concept of LA and the extent of English teaches' practices to promote LA. The participants were 33 private and state Senior High School English teachers who joined in Deliberation of Subject Teachers. The data, collected through questionnaire and interview, was analyzed using descriptive statistic and qualitative analysis. The findingsrevealed that majority participants (97\%) agreed or strongly agreedto technical view that independent study in the library was an activity which developed learner autonomy.In terms of Teacher Role, surprisingly, majority participants (64\%) disagreed or strongly disagreed to the statement that learner autonomy meant learning without a teacher.In promoting learner autonomy, $100 \%$ of the teachers often or always encouraged their students to be more responsible about what they did in class. Implications of this study are for the teachers' professional development and for promoting learner autonomy at senior high school level.
\end{abstract}

Keywords: English teachers, perception, practices, learner autonomy

DOI: $10.7176 / \mathrm{JEP} / 12-27-04$

Publication date:September $30^{\text {th }} 2021$

\section{Introduction}

Since National Curriculum of K-13 was launched, there has been a principle change of teacher's mindset in the way of teaching. The K-13 emphasizes learner-centered approach that gives students more portions of learning activities in the classroom. The teachers are encouraged to provide students wider space of activities that enables students to be more motivated, initiative, creative and independent in learning. Meanwhile, the teacher's role is as a learning facilitator for the students (Kemendikbud, 2014). This government policy becomes a momentum for English teachers to find some instructional approaches which meet the K-13's principals. One of the instructional approaches recently become a trending topic is learner autonomy (LA).

Autonomy, in the context of learning, is defined as the capacity to control one's own learning, to take a charge of or to be responsible for their own learning (Benson, 2011; Little, 1991; Dickinson, 1987; Holec, 1981).However, the definition mostly often quoted is from Holec (1981) that autonomy is defined as 'the ability to take charge of one's own learning. Benson (2011)says that for language learner autonomy, the capacity to make informed choices and decisions about their learning is important to persistence and success. He even argues that the choices and decisions are two important issues to autonomy for language learning, especially to the development of learner autonomy and professional development (Benson, 2016).

The present study focused on the evaluation of senior high school teachers' perception regarding LA and the teachers' practicesto promote LA.In the last decade, many research on the similar area were conducted by Asian researchers, but they mostly involved teachers at university level (Keuk and Heng, 2016;Loi, 2016; Madrunio and Trayo, 2016; Stroupe and Roundle, 2016; Tapinta, 2016; Wang and Wang, 2016). Lengkanawati (2016) found that that the teachers had more positive perceptions regarding LA. It was indicated by their strong agreements on the statements regarding LA related to the views on technology, psychology, politic and sociocultural.

This study was undertaken to find clear understanding of senior high school English teachers' perception of learner autonomy that could contribute to actual practices performed inside or outside the classroom. This paper will first report teachers' perception regarding LA and, second, the extent to which teachers' practices promote LA based on the data of questionnaire. The result of interview will support and validate the findings investigated from the data of questionnaire.

This research aims to investigate the answers to the following questions: How do senior high school teachers perceive the notion of LA? To what extent do the teachers' practicespromoteLA?

\section{Theoretical Framework}

It reviews 'Autonomy in Foreign Language Learning' and 'Promoting Learner Autonomy' sub topics that both aspects are used to deeply analyze and discuss the research findings.

\subsection{Autonomy in Foreign Language Learning}

Nowadays, the ideas on educating person, the changes in the traditional language learning system, and the 
teachers' roles in the learning and teaching process have been mostly significant to discuss. Autonomy, through a focus on learner reflection and taking responsibility for one's own learning processes, has become a central concern in the recent history of language teaching and learning (Dickinson, 1987; Holec, 1988; Little, 1991, 2007; Smith, 2000; Benson, 20007). In addition, autonomy in EFl or ESL has also become topic interest of studies that some of them connect and view it from the perspective of teacher's beliefs and practices (Borg and Saleh, 2012; Balcicanli, 2010; Barillaro, 2011). Other researchers may investigate other interesting sides of learner autonomy as topic of their research. It, at least, shows that the topic of learner autonomy or autonomous learning in EFL, ESL or ELT is still actually to investigate.

The term 'learner autonomy' has been a trending word in foreign language education in the past decades, especially in relation to lifelong learning skills. It has transformed old practices in the language classroom. Some experts may have different interpretation in understanding the concept of autonomy. Autonomy in learning is often understood about people taking more control over their learning in classrooms and outside them and autonomy in language learning is about people taking more control over the purposes for which they learn languages and the ways in which they learn them (Benson, 2007).

A definition about 'learner autonomy' was early given by (Holec, 1981) and now it still popular and influential that learner autonomy is defined as the ability to take charge of one's own learning, to have and to hold the responsibility for all the decisions concerning all aspects of this learning. He lists some specific decisions following the learner's responsibilities such as determining the objectives, defining the contents and progressions, selecting methods and techniques to be used, monitoring the procedure of acquisition and, evaluating what has been acquired. Dickinson (1987) adds that autonomy is a situation in which the learner is totally responsible for all the decisions concerned with his [or her] learning and the implementation of those decisions. It is strengthened by Little (1991) that autonomy is a capacity - for detachment, critical reflection, decision-making, and independent action.

'Learner autonomy' is as a mode of learning and this term is often used to describe a condition in which learners demonstrate a capacity to control their learning (Benson, 2013). This condition is also called studentcentered learning or flexible learning relates to the change in focus in the classroom from the teacher to the student or from the teaching to the learning (Taylor, 2000). This is based on a constructivist theory of learning whereby each individual student constructs their own understanding based on their prior knowledge and current learning experiences (Kember, 1997). More specifically when it is applied in language acquisition context, autonomy involves an ability to operate independently with the language and use it to communicate personal meanings in real, unpredictable situations. In classroom organization context, it involves learners' ability to take responsibility for their own learning and to apply active, personally relevant strategies. In a broader context, it involves a higher-level goal, that is a greater generalized autonomy as individuals (Holec, 1981).

\subsection{Promoting Learner Autonomy in Language Learning}

In the classroom, learning is commonly controlled by teachers. The classic teachers' assumption about teaching duty is mainly considered to transmit knowledge to the students. The teacher lecture and speak during most of the class time whilst students are required to listen to them and busy taking notes and then memorizing them rather than developing thoughts by talking to their fellow students or asking questions. The same thing still also happens to many language classrooms although practical approach should be stressed. To get rid of this condition, it needs to promote or foster the students to become independent or autonomous. Thus, in language teaching, the development of autonomy and self-sufficiency maybe desirable ends (Dickinson, 1994).

Some ways to develop learning activities can be tried as long as they are acceptable and enable to meet the desired goal. Communicative language teaching method tends to develop learner autonomy. In the communicative language teaching, language learners are expected to take on a greater degree of responsibility for their own learning, while teachers put themselves as facilitators helping learners to develop their own purposes in learning and giving them greater choice over their own learning, which involves the content and processes of learning, self-assessment and their use and awareness of learning-strategies (Richards, 2006). With proper and suitable efforts given by the teachers, learner autonomy in classroom or beyond the classroom can be promoted step-by-step.

Students have to be taught the skill 'how to learn' to encourage them to become more independent, or autonomous, in acquiring language skills. Holec (1981) states that promoting learner autonomy refers to encouraging students to determine the objectives, to define the contents and progressions, to select methods and techniques to be used, to monitor the procedures of acquisition and to evaluate what has been acquired. Through setting up directions in the planning, pacing, monitoring and evaluating the learning process, finally the autonomous learner can establish a personal agenda for learning (Little, 1994).

Autonomy cannot be 'taught' or 'learned', that is why the term 'fostering autonomy' is often used to refer to educational initiatives that are designed to stimulate or support 'the development' of autonomy among learners (Benson, 2013). Fostering or promoting learner autonomy can be performed through interesting and 
motivating learning activities. To do this, Kavaliauskiene (2003) suggests that teachers can encourage learners' development towards autonomy by motivating and involving students in class activities, producing classroom materials and using them in class or involving tasks and activities designed and administered by the learners themselves. The tasks may cover grammar, games, written work, audio- and video- recordings, news items, translation or anything that interest students will benefit them.

\section{Methods}

\subsection{Participants}

The participants of this research were 33English teachers of Senior High School selected purposely from those who joined in MGMP (Musyawah Guru Mata Pelajaran) or Deliberation of Subject Teachers of English Language in Jember, Indonesia. They were coming from 16 SMA Negeri or State Senior High Schools and 7 SMA Swasta or Private Senior High Schools consisted of 16 males and 17 females. They commonly held graduate qualifications and some of them were post graduate ones with teaching experience ranged from 3 to 32 years. Their ages ranged from 31 to 57 years old, and their qualifications were 4 Masters and 29 Bachelors. The MGMP meeting was conducted two-monthly, and each school commonly hadmore than 1 teacher joined the meeting.

\subsection{Instruments}

\subsubsection{Questionnaire}

This research adapted Borg and Al-Busaidi's questionnaire (Borg and Busaidi, 2012a) to get the data about LA concepts perceived by the English Language Teachers of senior high school in Jember containing 37 items. The items of questionnires were divided into five categories/views: technical (item 2, 6, 15 and 31), political(item 3, 4, 7, 14, 22 and 27), psychological (item 11, 29, 32, 33 and 37) and social (item 16, 19, 25 and 28). The rest of the items were related to other factors: teacher role (item 8, 18, 24 and 35), ages ( item 1, 10 and 20), English proficiency ( item 9, 26 and 34), culture ( item 13 and 23), learning achievement ( item 5 and 36), teaching approach ( item 12,17 and 30). The second questionnaire was about teachers' practices to promote learner autonomy containing 20 items. The response choices to the both questionnaires were designed in the form of linkert scale with five items. The questionnairesweregiven in Indonesian and distributed to 33 participants.

\subsubsection{Interview}

Follow-up interviews were employed after the questionnaire was distributed to elicit the teachers' opinion about LA in their own words. The interviews were also performed to get the data about their own classroom practices that they believedthat they can help students become autonomous learners. The interviewees were comprised six teachers, 3 males and 3 females, selected from the 33 participants represented the overall composition of the participants, mainly in the aspects of teaching experience (5 to 32 years), age (32 to 57 years old), school status (Private and State) and qualification (Bachelor to Master). All the interviews were conducted in Indonesian language and the data was saved in the form of recorded file. The interview asked about what the participants knew about LA and what activities potentially promoted learner autonomy that they most often did to their students, and what the reasons were. Among the 20 items of statements in questionnaire 2, the participants were free to choose which ones they often practiced.

\section{Research Findings}

The research findings based on each research question are briefly reported in this section. The findings are drawn from the teachers' responses to the questionnaires and from their comments as a response to the interview stage.

\subsection{Research Question 1: Teachers' Perception Regarding Learner Autonomy}

The data about participants' perception regarding learner autonomy is categorized into four views: political, social, technical and psychological. The following chart shows frequency of positive responses concerning the four views.

Chart1.The Statistics of Participants'Positive Responses Regarding Learner Autonomy by View 


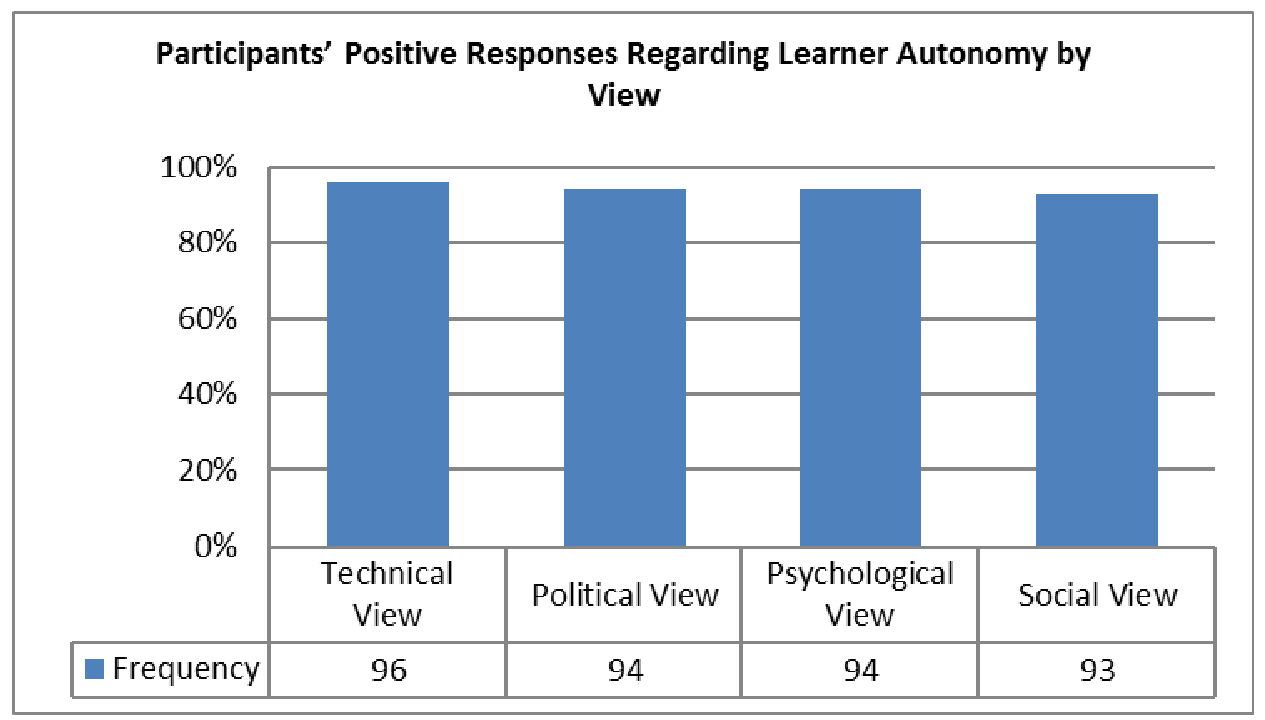

Among the six viewsabove, Technical view got the most majority positive response, $96 \%$ of the participants agree or strongly agree to the statement no. 2 that independent study in the library was an activity which developed learner autonomy. It is mostly commented by the participants that one of the statements (by Teacher 3 ) is highlighted below:

"I often ask my students to go to library, especially when their teacher doesn't come. I think library is a place where students can study by themselves and read any book they like." (T3)

The second majority responses belonged to the political view(two statements) and psychological view (one statement). Both viewsgot $94 \%$ agreeor strongly agree from the participants. Statement no. 3 in Political view stated that $L A$ was promoted through regular opportunities for learners to complete tasks alone (supported by T2's comment).

"Learner autonomy can be promoted when the teacher provides a suitable place or facility as well as some materials to choose and learn by the learners. The school policy in making flexible rules " (T2)

"I think autonomy is a kind of freedom for the students to decide how they learn the material. They want to find the suitable way of learning they like." (T4)

Statement no. 11 in Psychological View stated that confident language learners were more likely to develop autonomy than those who lacked confidence. This statement had got $94 \%$ agree and strongly agree, andsupported by Teacher 5 and Teacher 6.

"The learners who are better in terms of self-confedence are easier to be independent in learning than those who are not." (T5)

"It is difficult for the learners to be autonomous when they are unmotivated to learn." (T6)

In Social View, majority participants (93\%) agreed or strongly agreed with the perception no.16 that $L A$ was promoted through activities which give learners opportunities to learn from each other. This agreement had got a support from Teacher 1. His argument was linier with statement that was mostly perceived by the participants. He said that peer assistance should be built among the learners.

"Some task given by the teachers could be done or solved together among the learners without any teachers' assistance." (T1)

Out of the four views, the rest of questionnaire items are categorized into six factors: teacher role, ages, English proficiency, culture, learning achievement, teaching approach. The data displayed in the following chart are positive responses frequency regarding Learner Autonomy by other factors.

Chart2. Statistics of Participants' Positive Responses Frequency Regarding Learner Autonomy by other Factors 


\section{Teachers' Positive Responses regarding Learner Autonomy by other Factors}

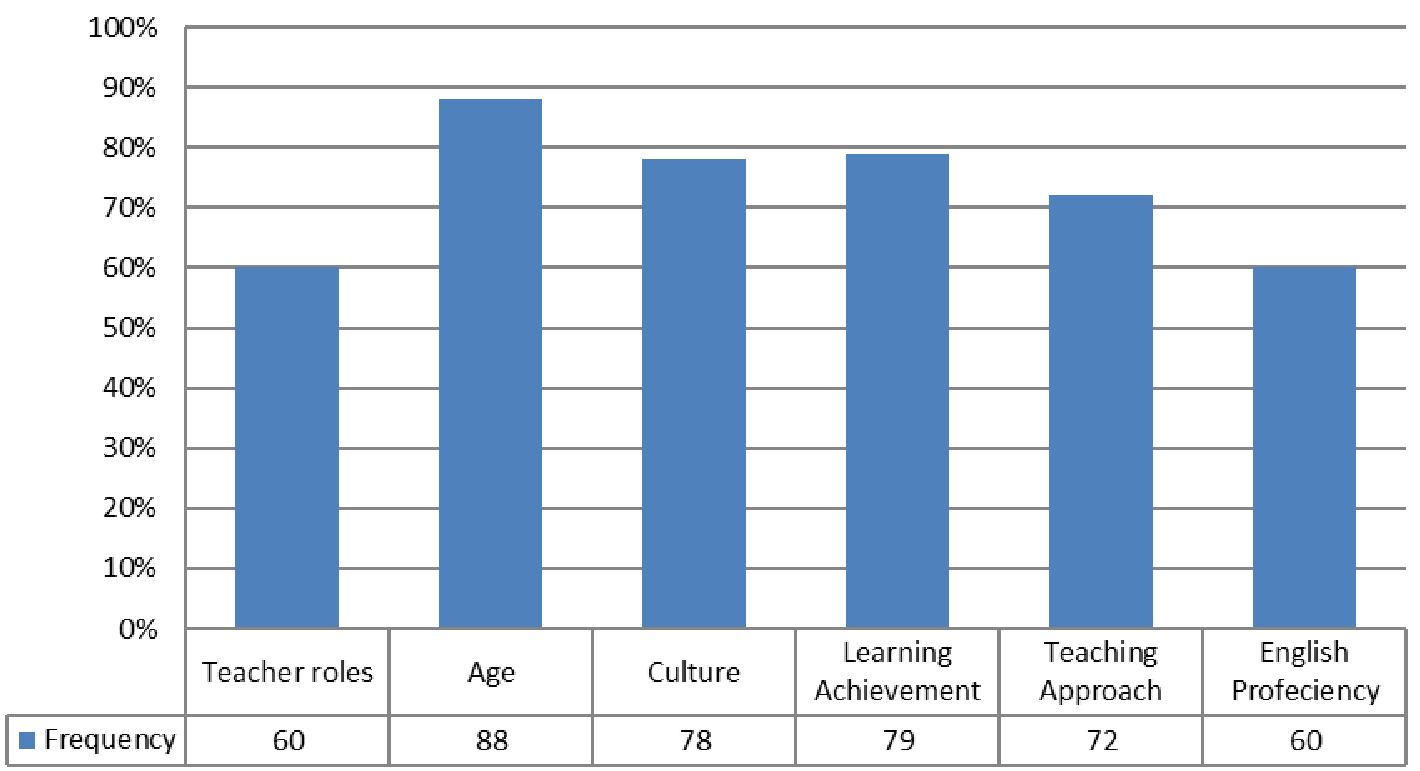

RegardingTeacher Role factor, majority participants (64\%) disagreed or strongly disagreed to the perception that learner autonomy meant learning without a teacher; only $60 \%$ for those who agreed or strongly with that the teacher had an important role to play in supporting learner autonomy. It means learners still needed teachers to help them once in a while or to be put as a learning facilitator.

"I belief that the teacher's presence is still required to assist learners when they are working their tasks." (T1)

As Age factor was chosen, the majority participants (88\%) agreed or strongly agreed with the perception that language learners of all ages could develop learner autonomy. Almost all the interviewees believed that to be learner autonomy did not need to wait until the learners grew adult but it could began from kindergarten.

"To be an autonomous learner can be begun earlier, even when a learner just started to study in a formal school."

Meanwhile, majority perception of the participants to the factor of Culture, $78 \%$ of themagreed or strongly agreed that LA could be achieved by learners of all cultural backgrounds. The teachers perceived that any cultural background of the learners' were believed to help develop LA.The following is one of the participants' comment.

"I don't know if Indonesian students from any cultural background/ ethnic can be learner autonomy, but I belief they can when they are given chances and encouragement to practice." (T3)

Regarding Learning Achievement factor, majority participants (79\%) agreed or strongly agreed to the concept that LA had a positive effect on success as a language learner. The participants often found that their students who were autonomous in learning were good in learning performance. One of the participants (T5) gave her comment as follows.

"I am as an English teacher often find and belief that independent students are able to learn English better than those who are not. I often witness it in my own classes." (T5)

In terms of Teaching Approach, majority participants (72\%) agreed or strongly agreed with the concept that $L A$ was promoted when learners could choose their own learning materials. Some of participants' comments support the above findings are highlighted below.

"It is not easy to become learner autonomy. There are many factors envolved in promoting students become LA, one of them is providing some additional materials...so that the students have choices to read, especially in the library." (T6)

In English Proficiency factor, statement saying that the proficiency of a language learners did not affect their ability to develop autonomy was agreed and strongly agreed by $60 \%$ of the voters. Some of them had got reasons that basically learner autonomy could be effectively developed when the learners had better learning proficiency.

"I found my students whose their language abilities are good can develop their independency in learning with less or without assistance."

In this context, the freedom of selecting various materials provided by the teacher could promote learner autonomy. Of course, preparing various selected materials requires energy, time and even money for teachers. 
However, this responsibility will have a very positive impact on students.

\subsection{Research Question 2: The extent to which Teachers' Practices Promote LA}

The teacher activities in relation to the efforts of promotinglearner autonomy among senior high school students are depicted in the following chart.

Chart 3.The teachers' activities to promote learner autonomy

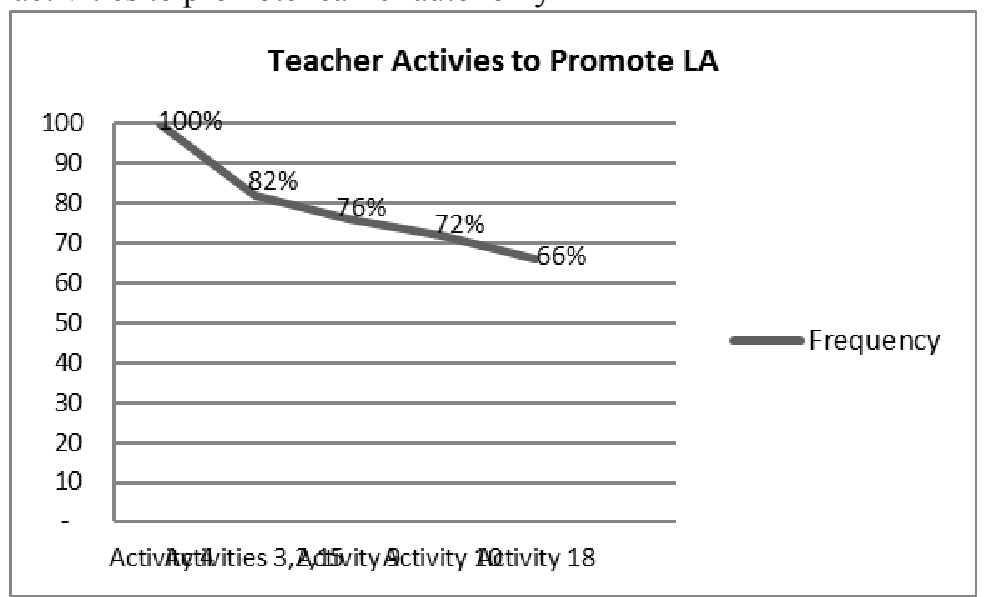

The data in Chart3shows the rank of practices performed by the English teachers regarding the promotion to be LA. Rank 1 to 5 are the practices that $\geq 75 \%$ of participants often performed. Start from rank 1 , statement number 4 reveals that $100 \%$ ofparticipants often or always encouraged their students to be more responsible about what they did in class. It was the most often practiced by the teachers and they believed that it could promote LA. The participants also confirmed their choice by commenting as follows:

"Class is a place where they can interract each other; example, discussion, doing tasks etc. students should be responsible to what they have done." (T1)

In the second rank, there were three practices (statement number 3, 2 and 15) which $82 \%$ of participants often or always performed: a) encouraging students to go the extra mile and not be afraid to make mistakes, going a long way in making them confident to work by themselves, b)asking students to do co-operative and peer learning wherever possible; and c) telling students that knowledge was always available around them, but all that they need were the incentive and the method to find it.According to the collected data, all the three practices were coincidentally carried out by the same number of teachers. They convinced by expressing their opinion as follows.

"Doing mistake in learning language is common and acceptable. Students should be encouraged not to be affraid in making mistakes." (T4)

"Encouraging students not to be afraid of making mistake when doing tasks in the class or at home." (T2)

'Asking students to go to some places related to the being discused topics, ex. In Supermarkets, Malls, Tourist Resorts etc." (T3)

Rank 3, statement number 9, wasthe teachers did their best to involve their students in reflection into students' individual learning preferences and strategies.It waspracticedby $76 \%$ of the teachers in promoting LA.Those findings were supported with their comments displayed as follows.

"I invite the students to get involved in discussion about their preferences in learning and what strategies fit them."

"Students should be encouraged and motivated not to stop learning and they must be confident that they can become LA." (T2)

The forth mostly performed activity to promote LA was that the teachers encouraged their students to further their learning of English in situations outside the classroom without help from any teacher. This activity was performed by $72 \%$ of the teachers. It is reasonable that to build learner autonomy, trying to be independent from the teacher's assistance is effective. The following statements conveyed by Teacher 5 (T5) and Teacher 4 (T4) confirmed that activity.

"I often ask students to learn independently using their own gadgets or other electronic devices such as laptop or PC anywhere, especially when they are at home." (T5)

The last rank ofactivity often or always performed by the teachers was giving Independent Learning Projects in the courses they have taught, and it was considered as good examples of promoting the learners' autonomy. This activity was often undertaken by $66 \%$ of participants. A verbal statement below is an example to reinforce that choice. 
“Giving students opportunities to complete projects individually or in group at school or at home could help students become more independent." (T4)

The various activities mentioned above are real descriptions that were often and always carried out by teachers in relation to efforts to help students become independent learners. Even if seen from the aspect of frequency, those activities had a different number of voters.

\section{Discussion}

The findings of the current study reveal that,Technical View got the most majority response, $97 \%$ of the participants agreed or strongly agreed. It was followed by the second majority response in Political View (two statements) and Psychological View (one statement),both got 94\% agree or strongly agree. The response to social view indicated that the majority participants, $93 \%$, agreed or strongly agreed. This finding suggests that the teachers' perception represents their understandingon the concept of LA mostly leadto technical view first, and then followed bypolitical view, psychological viewand, the last, social view.Borg and Busaidi (2012a)reported the result differently that the most agreed response wasaddressed to psychologicalview, and then followed by political, technical and finally social. In this study, the orientation of the agreement mostly addressed to technical view was affected by the participants' understanding about the concept of LA. They knew LA as independent study that was mostly related to the way of learning, more mechanical.

In the context of Asean countries, Indonesian senior high school English teachers held a bit different perception on the notion of LA with teachers in other Asean countries. In Vietnam, for example, the statement covered in Political View that " autonomy means that learners can make choices about how they learn," (statement 4 ) was agreed or strongly agreed by $77.4 \%$ of majority Vietnam's teacher (Loi, 2016) and by $83 \%$ of Cambodian ELT teachers (Keuk and Heng, 2016). Meanwhile, this research found that 94\% of the participants agreed or strongly agreed with the same statement. Their positive perceptions on the statement were supported with their comments that autonomy was a kind of freedom for the students to decide how they learn the material (T4). Taken from percieving one of LA concepts above, it reveals that more Indonesian senior high school English teachers had almost similar perception about the notion of LA as described in the questionnaire by Borgand Al Busaidi (2012a).

The statement about language learners of all ages could develop learner autonomy was perceived by $88 \%$ of majority participants.It refers to a concept theorized by Benson (2016)thatpromoting LA in second or foreign language teaching is, in fact, begun at early age. It was also proved by the participants when they were asked to vote whether they agreed that it was harder to promote learner autonomy with proficient language learners than it was with beginners, more than a half of them (52\%) agreed or strongly agreed. Thus, developing LA for foreign or second language learner should be begun early age.

The teachers' practice regarding LA that all participants often or always performed was encouraging their students to be more responsible about what they did in class. Borg and Al-Busaidi's survey (2012b) believed that the teachers' teaching gave their students opportunities to develop learner autonomy. This research finding confirmed that there were three practices that $82 \%$ of participants were a) encouraging not to be afraid of making mistakes, be confident to work by themselves, b) asking students to do co-operative and peer learning wherever possible; and c) telling students that knowledge was always available around thembut all that they need were the way and the method to find it. It reveals that what the teachers often practiced so far was a psychological encouragement that they believed it could promote students to be autonomous learners. In some cases, Van Loi (2016) confirmed that when learners lacked confidence it could influence the decision on their own learning process. Thus, psychological factor plays an important role in promoting LA.

\section{Conclusion}

The main findings of this study are that high school English teachers had a good perception of the concept of LA based on their own understanding, even though they had not received introductory courses on LA, and they had implemented good practices in terms of encouraging students to become autonomous learners. Regarding perceptions about LA, they provided the majority agree or strongly agree with statements that, perhaps, they rarely read theoretically. Their good perceptions can be considered as the main capital and an important component for developing the autonomy of students. They claimed to have done practical and exhilarating activities to promote LA. Their recognition of the practice of promoting LA to their students indicates a positive effort to involve students in outdoor or classroom tasks to promote autonomous learning behavior. Better understanding by teachers concerning LA principles is believed to give effect on better practical performance regarding LA development, especially for High School students.

\section{Acknowledgements}

On this occasion I would like to express my deep gratitude to Prof. Dr. Lies Amin Lestari, MA., M.Pd and Slamet Setyawan, Ph.D, who have been willing to be the second and third writers and have guided me to make 
my article better. My gratitude goes to Dr. Supriyatno, SS., MPd for his assistance in preparing this scientific article for publication and also to IISTE for accepting and publishing this article.

\section{References}

Barillaro, Francisco. 2011. Teacher perspectives of learner autonomy in language learning. MA Dissertation, TESOL Centre, Sheffield Hallam University

Balçıkanlı, Cam. 2010. Learner Autonomy In Language Learning: Student Teachers' Beliefs. Australian Journal of Teacher Education, 35(1).

Benson, Phil. 2016. Language Learner Autonomy: Exploring Teachers' Perspectives on Theory and Practices. In Barnard, R. and J. Li (Eds.) Language Learner Autonomy: Teachers' Beliefs and Practices in Asian Context (pp. xxxiii-xlii).Phnom Penh: IDP Education (Cambodia) Ltd.,

Benson, Phil. 2011.Teaching and Researching Autonomy ( $2^{\text {nd }}$ ed). London, England: Pearson Education

Borg, Simon and Al Busaidi, Saleh.2012a.Teachers' Beliefs and Practices Regarding Learner Autonomy.English Language Teaching Journal, 33 (3), 283-292. Available at http://dx.doi.org/10.1093/elt/ccr065

Borg, Simon and Al Busaidi, Saleh. 2012b. Learner Autonomy: English Language Teachers' Belief and Practices (ELT Research Paper 12-07). London England: British Council

Dickinson, Leslie. 1987.Self-instruction in Language Learning. New York: Cambridge University Press

Holec, Henri. 1981.Autonomy and Foreign Language Learning. Oxford, England: Pergamon

Kavaliauskiene,Galina. 2003. Two Activities for Fostering Autonomous Learning. The Internet TESL Journal, Vol. IX, No. 7, July 2003.http://itesli.org/

Kemendikbud. 2014. Konsep Dan Implementasi Kurikulum 2013. Available in http://kemdikbud.go.id/kemdikbud/dokumen/Paparan/ Paparan\%20Wamendik.pdf,

Keuk, Chan N. and Heng, Vileak.2016. Cambodian ELT Teachers Through Professional Development. In Barnard, R. and J. Li (Eds.) Language Learner Autonomy: Teachers' Beliefs and Practices in Asian Context (pp. 62-78).Phnom Penh: IDP Education (Cambodia) Ltd

Lengkanawati, Nenden S. 2016.Teachers' Belief about Learner Autonomy and Its Implementation in Indonesian EFL Setting. In Barnard, R. and J. Li (Eds.) Language Learner Autonomy: Teachers' Beliefs and Practices in Asian Context (pp. 134-149).Phnom Penh: IDP Education (Cambodia) Ltd.

Little, David. 1991. Learner Autonomy: Definitions, Issues and Problem. Dublin, UK: Authentic

Loi, Nguyen Van.2016.Learner Autonomy in Vietnam: Exploring Teacher Perspective and Practice. In Barnard, R. and J. Li (Eds.) Language Learner Autonomy: Teachers' Beliefs and Practices in Asian Context (pp. 18).Phnom Penh: IDP Education (Cambodia) Ltd.

Madrunio, Marilu R., Trayo, Veronico N.,Tupas, Ruanni and Valdez, Paulo N. 2016. Learner Autonomy: English Language Teachers'Beliefs and in the Philipines. In Barnard, R. and J. Li (Eds.) Language Learner Autonomy: Teachers' Beliefs and Practices in Asian Context (pp. 114-133).Phnom Penh: IDP Education (Cambodia) Ltd.

Richard, Jack. 2006. Communicative Language Teaching. New York: Cambridge University Press

Smith, Richard C. 2000. Starting with ourselves: Teacher-learner autonomy in language learning. In B. Sinclair, et al. (Eds.), Learner autonomy, teacher autonomy: Future directions. pp.89-99. London: Longman.

Stroupe, Richmond and Roundle, Collin and Tomita, Koki. 2016, Developing Autonomous Leaner in Japan: Working with Teachers Through Professional Development. In Barnard, R. and J. Li (Eds.) Language Learner Autonomy: Teachers' Beliefs and Practices in Asian Context (pp. 43-61).Phnom Penh: IDP Education (Cambodia) Ltd.

Tapinta, Pataraporn. 2016. Thai Teachers' Beliefs inDeveloping LearnerAutonomy: L2 Education in Thai Universities. In Barnard, R. and J. Li (Eds.) Language Learner Autonomy: Teachers' Beliefs and Practices in Asian Context (pp. 98-113).Phnom Penh: IDP Education (Cambodia) Ltd.

Wang, Yi and Wang, Ming-Xin. 2016. Developing Learner Autonomy: Chinese University EFL Teachers' Perception and Practices. In Barnard, R. and J. Li (Eds.) Language Learner Autonomy: Teachers' Beliefs and Practices in Asian Context (pp. 23-42).Phnom Penh: IDP Education (Cambodia) Ltd. 


\section{Appendixes}

Appendix 1. English language Teacher's Perceptions About Learner Autonomy Adapted from Borg and Al-Busaedi (2012, pp.26-27)

No. Statement

1. Language learners of all ages can develop learner autonomy.

2. Independent study in the library is an activity which develops learner autonomy.

3. Learner autonomy is promoted through regular opportunities for learners to complete tasks alone.

4. Autonomy means that learners can make choices about how they learn.

5. Individuals who lack autonomy are not likely to be effective language learners.

6. Autonomy can develop most effectively through learning outside the classroom.

7. Involving learners in decisions about what to learn promotes learner autonomy.

8. Learner autonomy means learning without a teacher.

9. It is harder to promote learner autonomy with proficient language learners than it is with beginners.

10. It is possible to promote learner autonomy with both young language learners and with adults.

11. Confident language learners are more likely to develop autonomy than those who lack confidence.

12. Learner autonomy allows language learners to learn more effectively than they otherwise would.

13. Learner autonomy can be achieved by learners of all cultural backgrounds.

14. Learner autonomy is promoted when learners have some choice in the kinds of activities they do.

15. Learner autonomy cannot be promoted in teacher-centred classrooms.

16. Learner autonomy is promoted through activities which give learners opportunities to learn from each other.

17. Learner autonomy implies a rejection of traditional teacher-led ways of teaching.

18. Learner autonomy cannot develop without the help of the teacher.

19. Learner autonomy is promoted by activities that encourage learners to work together.

20 Learner autonomy is only possible with adult learners.

21. Learner autonomy is promoted by independent work in a self-access centre.

22. Learner autonomy is promoted when learners are free to decide how their learning will be assessed.

23. Learner autonomy is a concept which is not suited to non-Western learners.

24. Learner autonomy requires the learner to be totally independent of the teacher.

25. Co-operative group work activities support the development of learner autonomy.

26. Promoting autonomy is easier with beginning language learners than with more proficient learners.

27. Learner autonomy is promoted when learners can choose their own learning materials.

28. Learner-centred classrooms provide ideal conditions for developing learner autonomy.

29. Learning how to learn is key to developing learner autonomy.

30. Learning to work alone is central to the development of learner autonomy.

31. Out-of-class tasks which require learners to use the internet promote learner autonomy.

32. The ability to monitor one's learning is central to learner autonomy.

33. Motivated language learners are more likely to develop learner autonomy than learners who are not motivated.

34. The proficiency of a language learner does not affect their ability to develop autonomy.

35. The teacher has an important role to play in supporting learner autonomy.

36. Learner autonomy has a positive effect on success as a language learner.

37. To become autonomous, learners need to develop the ability to evaluate their own learning. 
Table 2. Teacher's practices to promote learner autonomy adapted from Borg and Al-Busaidi (2012, pp. 37).

\begin{tabular}{|c|c|}
\hline No. & Statements \\
\hline 1. & $\begin{array}{l}\text { Asking students to go to the library and do Moodle assignments are part of learning that develops } \\
\text { autonomy. }\end{array}$ \\
\hline 2. & Asking students to do Co-operative and peer learning wherever possible. \\
\hline 3. & $\begin{array}{l}\text { Encouraging students to go the extra mile and not be afraid to make mistakes, goes a long way in } \\
\text { making them confident to work by themselves. }\end{array}$ \\
\hline 4. & Encouraging them to be more responsible about what they do in class. \\
\hline 5. & I actively promote learner autonomy in my lessons using worksheets. \\
\hline 6. & I ask students to tell me the mark they hope to get in their presentations and how they can get that mark. \\
\hline 7. & I ask them to find out about certain topics and be ready to discuss them in the next lesson. \\
\hline 8. & I constantly give homework and tasks to be completed and brought back to the classroom. \\
\hline 9. & I do my best to involve my students in reflection into their individual learning preferences and strategies. \\
\hline 10. & $\begin{array}{l}\text { I encourage them to further their learning of English in situations outside the classroom without help } \\
\text { from any teacher. }\end{array}$ \\
\hline 11. & I have the class choose which activities they want to do in some cases. \\
\hline 12. & $\begin{array}{l}\text { I negotiate with students on deadlines for assignments, topics for presentations and speaking as well as } \\
\text { readers (they can change a reader assigned to them if they don't like it). }\end{array}$ \\
\hline 13. & $\begin{array}{l}\text { I spend quite a lot of time with my students explaining the benefits and the different ways of developing } \\
\text { autonomy. }\end{array}$ \\
\hline 14. & I talk to them regularly about why we are doing what we are doing and the bigger picture. \\
\hline 15. & $\begin{array}{l}\text { I tell them that knowledge is always available around you, but all that you need are the incentive and the } \\
\text { method to find it. }\end{array}$ \\
\hline 16. & $\begin{array}{l}\text { I try to promote it by not answering the questions they have sometimes and by telling them to go find the } \\
\text { answer themselves. }\end{array}$ \\
\hline 17. & I usually encourage them to visit the library and practice different tasks on extensive reading. \\
\hline 18. & $\begin{array}{l}\text { Independent Learning Projects in the courses I have taught are good examples of promoting the learners' } \\
\text { autonomy. }\end{array}$ \\
\hline 19. & Peer assessments of students' work at classroom level is encouraged. \\
\hline 20. & $\begin{array}{l}\text { Sometimes I ask students to tell me what they have learned during the week, what they have found, easy, } \\
\text { difficult, and what they should do to improve. }\end{array}$ \\
\hline
\end{tabular}

